\title{
Bacterial capsules: no barrier against Bdellovibrio
}

\author{
Susan F. Koval ${ }^{1}$ and Manfred E. Bayer ${ }^{2}$ \\ Author for correspondence: Susan F. Koval. Tel: +1 519661 3439. Fax: +1 5196613499. \\ e-mail:skoval@julian.uwo.ca
}

\footnotetext{
1 Department of Microbiology and Immunology, University of Western Ontario, London, ON N6A 5C1, Canada

2 Fox Chase Cancer Center, Institute for Cancer Research, 7701 Burholme Avenue, Philadelphia, PA 19111, USA
}

\begin{abstract}
Bdellovibrio bacteriovorus $109 \mathrm{~J}$ attached to both capsulated and noncapsulated Escherichia coli K29 cells. Electron microscopy revealed penetration of the thick polysaccharide capsule without any major disintegration of the neighbouring capsular matrix. The capsule remained intact during bdelloplast formation and lysis was unaffected by capsulation of the prey cell. This study shows that, in contrast to its effect on bacteriophage penetration and its protective activities against immune defence mechanisms, the capsule of $E$. coli does not serve as a barrier against invasion by $B$. bacteriovorus.
\end{abstract}

\section{INTRODUCTION}

Bdellovibrio bacteriovorus is a small, rapidly motile Gram-negative bacterium that uses another Gramnegative bacterium as its sole source of nutrition. The most significant taxonomic characteristic of the genus Bdellovibrio is the presence of an intracellular growth phase within the periplasmic space of an invaded bacterium (Burnham \& Conti, 1984). The life cycle of wild-type bdellovibrios alternates between an extracellular, flagellated, but non-growing phase and an intracellular, non-flagellated, periplasmic growth phase. The process of recognition and attachment to prey cells by $B$. bacteriovorus is complex and not completely understood. The range of susceptible prey cells varies with the Bdellovibrio strain but is restricted to Gramnegative bacteria. B. bacteriovorus probably encounters its prey cells solely by random collision, because no signalling mechanisms have been identified in the location of specific prey (Gray \& Ruby, 1991).

The mechanism of attachment and penetration appears to be a two-step procedure (Dunn et al., 1974). The initial, reversible stage of attachment following collision is characterized by a loose association in which the bdellovibrio cell rotates about its long axis from the point of attachment to the prey cell surface. It may stop rotating, then start again, or suddenly detach and swim away. Reversible attachment can be non-specific and involve inert surfaces such as microscope slides or cover slips, or non-suitable prey cells (i.e. Gram-positive bacteria). To form an irreversible attachment, the bdellovibrio cell forms a tight junction with the prey cell, which itself begins to rotate about the long axis of the bdellovibrio cell. The two cells then spin as a unit, with the bdellovibrio cell pushing the prey cell through the suspending medium. This irreversible stage of attachment is quickly followed by detachment of the flagellum and penetration into the prey cell. The involvement of specific receptor interactions in prey recognition has been investigated (Gray \& Ruby, 1991) but a specific receptor, even for one strain of Bdellovibrio, has not been identified. The question of cell-surface barriers to attachment and penetration of bdellovibrios has rarely been addressed but does arise when the function of surface structures of bacteria is considered. Koval \&. Hynes (1991) have shown that paracrystalline protein surface layers (S-layers) protect Gram-negative cells against predation by $B$. bacteriovorus.

This study examines the effect of capsules of Escherichia coli on predation by B. bacteriovorus. E. coli K29 was used since its capsule has been well-characterized biochemically (Fehmel et al., 1975), crystallographically (Moorhouse et al., 1977) and morphologically (Bayer et al., 1985). As controls, two non-capsulated strains were used: E. coli ${\mathrm{K} 29^{-}}^{-}$(a stable revertant of $\mathrm{K} 29$ to a noncapsulated form) and E. coli ML35 (the E. coli strain upon which $B$. bacteriovorus $109 \mathrm{~J}$ is maintained). $B$. bacteriovorus strain 109J was selected because it is one of the best-studied strains of B. bacteriovorus (Ruby, 1992; Gray \& Ruby, 1991).

\section{METHODS}

Culture conditions. All E. coli strains were maintained on slants of trypticase soy agar at $4^{\circ} \mathrm{C}$. B. bacteriovorus was maintained on prey cells of $E$. coli ML35 as described by Koval \& Hynes (1991). Lysates containing B. bacteriovorus were stored at $4{ }^{\circ} \mathrm{C}$ in screw-capped test tubes. 
To assay predation, two-membered culture systems were set up, using a modification of the procedure of Koval \& Hynes (1991) described here. E. coli $\mathrm{K} 29$ and $\mathrm{K}^{2} 9^{-}$were grown in Lbroth ( $1 \%$ tryptone, $0.5 \%$ yeast extract, $0.5 \% \mathrm{NaCl}, \mathrm{pH} 7 \cdot 0)$ containing $0.5 \%$ glucose for $24 \mathrm{~h}$ at $30^{\circ} \mathrm{C}$ with shaking. E. coli ML35 was grown in L-broth (without glucose) under the same conditions. After $24 \mathrm{~h}$ growth, E. coli $\mathrm{K} 29$ cells had a large, well-defined capsule, as visualized by India ink and other stains (Bayer, 1990). The production of capsules was not as good on cells grown on agar medium. Thirty-five millilitres of each culture was centrifuged aseptically at $12000 \mathrm{~g}$ for $20 \mathrm{~min}$ and each pellet resuspended in $10 \mathrm{ml} 25 \mathrm{mM}$ HEPES plus $2 \mathrm{mM} \mathrm{CaCl}_{2}$ buffer at $\mathrm{pH} 7 \cdot 8$ (HEPES plus $\mathrm{Ca}^{2+}$ ). The E. coli K29 cells retained their capsule after centrifugation and resuspension in buffer. To $35 \mathrm{ml}$ of HEPES plus $\mathrm{Ca}^{2+}$ buffer in a $250 \mathrm{ml}$ side-arm flask with baffles, $5 \mathrm{ml}$ of a prey cell suspension and $5 \mathrm{ml}$ of a fresh B. bacteriovorus 109J lysate were added. Control cultures of prey cells in buffer alone were set up in side-arm flasks without baffles. To these flasks, $5 \mathrm{ml}$ buffer was added instead of B. bacteriovorus. All flasks were incubated at $30^{\circ} \mathrm{C}$ with shaking and predation monitored by phase-contrast microscopy. Turbidity measurements were taken on a Klett-Summerson photoelectric colorimeter fitted with a green filter (no. 54). For reference, the approximate equivalence in $\mathrm{OD}_{580}$ for the initial and final turbidities of the E. coli $\mathrm{K} 29$ two-membered culture are: $150 \mathrm{Klett}$ units $=0.9$ $\mathrm{OD}_{580}$ units; 105 Klett units $=0.5 \mathrm{OD}_{580}$ units.

Electron microscopy. Samples $(2.5 \mathrm{ml})$ of E. coli $\mathrm{K} 29$ cells were exposed to $1 \mathrm{ml} \mathrm{B}$. bacteriovorus and the culture shaken at $30^{\circ} \mathrm{C}$. After $45 \mathrm{~min}$ (when many B. bacteriovorus cells had attached to $E$. coli rods), the cells were centrifuged for $5 \mathrm{~min}$ at $3700 \mathrm{~g}$, resuspended in $1.5 \mathrm{ml} 0.1 \mathrm{M}$ sodium phosphate buffer ( $\mathrm{pH} 7$ ) and $0.5 \mathrm{ml}$ anti-capsule K29 serum (rabbit) added to stabilize the capsule and prevent further penetration of the capsule. The cells agglutinated within 10-20 s. After $10 \mathrm{~min}$ at $4{ }^{\circ} \mathrm{C}$, the cells were centrifuged $(2 \mathrm{~min}$ at $2000 \mathrm{~g}$ ) and the pellet resuspended in $2 \mathrm{ml} 0.1 \mathrm{M}$ cacodylate buffer containing $2 \%$ glutaraldehyde and $1 \%$ formaldehyde, both diluted from $25 \%(\mathrm{v} / \mathrm{v})$ and $16 \%(\mathrm{v} / \mathrm{v})$ solutions, respectively. After $60 \mathrm{~min}$ at $4{ }^{\circ} \mathrm{C}$ and centrifugation at $2000 \mathrm{~g}$, the pellet was overlaid with cacodylate buffer for $15 \mathrm{~min}$. After removal of the buffer, the cells were post-fixed in $1 \%(\mathrm{w} / \mathrm{v}) \mathrm{OsO}_{4}$ for $40 \mathrm{~min}$ in cacodylate buffer, washed in buffer, dehydrated in an alcohol series and embedded in Spurr resin. Sections were post-stained with uranyl acetate and lead citrate and examined in a Philips 420 electron microscope.

\section{RESULTS AND DISCUSSION}

E. coli strains K29 and K29- (Fig. 1) and ML35 (Fig. 2) were all susceptible to predation by $B$. bacteriovorus $109 \mathrm{~J}$. After $1-3 \mathrm{~h}$, bdellovibrios were attached to E. coli cells both with (Fig. 3b) and without capsules (data not shown). After $5 \mathrm{~h}$, many bdelloplasts and free-swimming bdellovibrios were seen in all cultures, but very few rod-shaped E. coli. By 7 h, the E. coli $\mathrm{K} 29$ and $\mathrm{K} 29^{-}$twomembered cultures contained mostly free-swimming bdellovibrios. Those bdelloplasts present often had many (10-15) bdellovibrios attached on the outside. At 7 h, the E. coli ML35 plus B. bacteriovorus culture had more bdelloplasts present than the K29 culture, but then the initial turbidity (i.e. the number of E. coli cells) was higher than for the E. coli $\mathrm{K} 29$ and K29- cultures. By 9 h, all lysates contained only free-swimming bdellovibrios. The turbidity of the control cultures of each E. coli

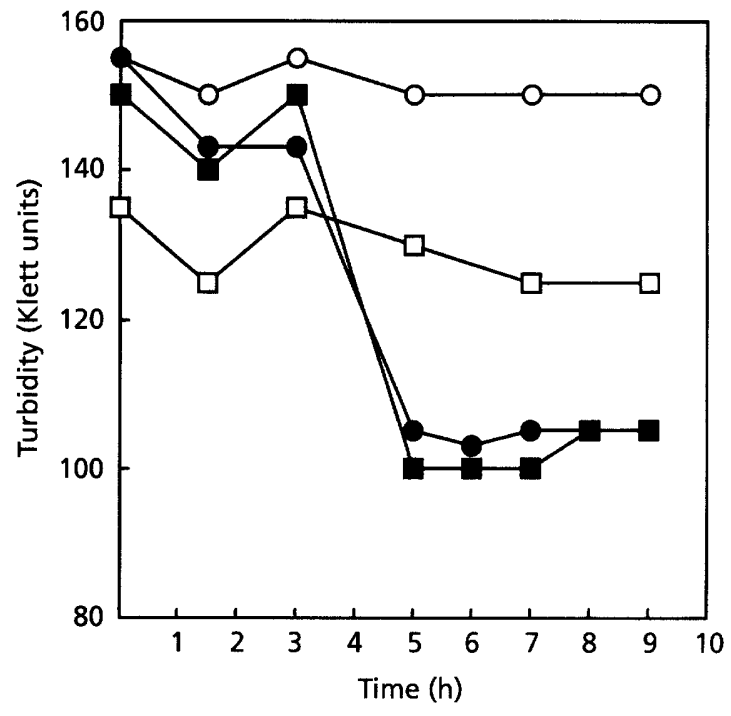

Fig. 1. Predation of E. coli K29 by B. bacteriovorus 109J. $\square, \square$ Capsulated strain $\mathrm{K} 29 ; \mathrm{O}$, non-capsulated strain $\mathrm{K}_{2} 9^{-}, \square, \mathrm{O}^{\prime}$ Cells in buffer alone; $\mathbf{\square}$, cells in buffer plus $B$. bacteriovorus.

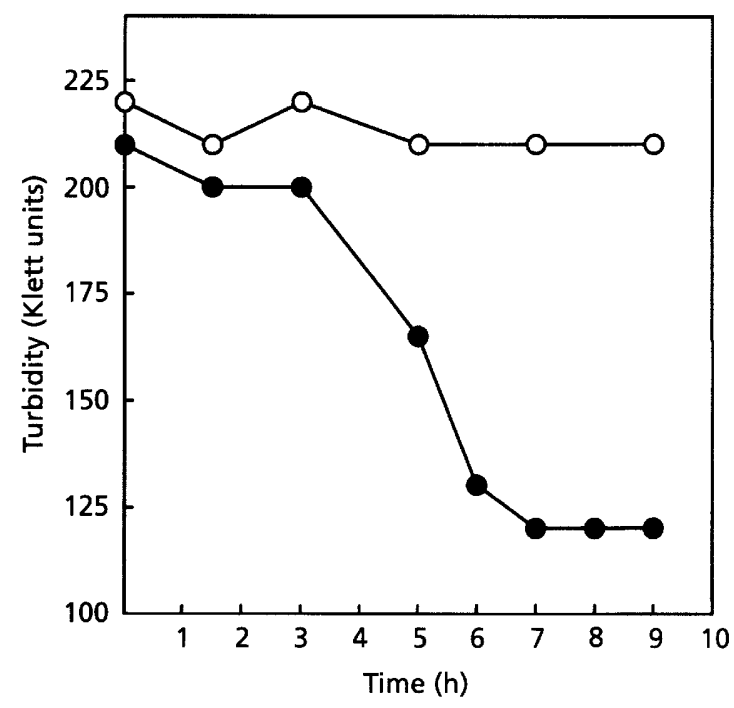

Fig. 2. Predation of $E$. coli ML35 by $B$. bacteriovorus 109J. $O$, Cells in buffer alone;, cells in buffer plus $B$. bacteriovorus.

strain in buffer did not decrease significantly. There was no difference in the time it took for the turbidity of the two-membered E. coli $\mathrm{K} 29$ and $\mathrm{K} 29^{-}$cultures to decrease (Fig. 1). Thus the capsule of E. coli K29 was not an effective barrier against attachment and penetration of B. bacteriovorus $109 \mathrm{~J}$.

The capsule of E. coli $\mathrm{K} 29$ comprises polysaccharide fibres which exhibit strong negative charges due to the glucuronic acid and pyruvate residues of their subunits (Fehmel et al., 1975; Bayer \& Sloyer, 1990). Individual fibres extend through the capsule's entire thickness of several hundred nanometres (Bayer, 1990). Although the 

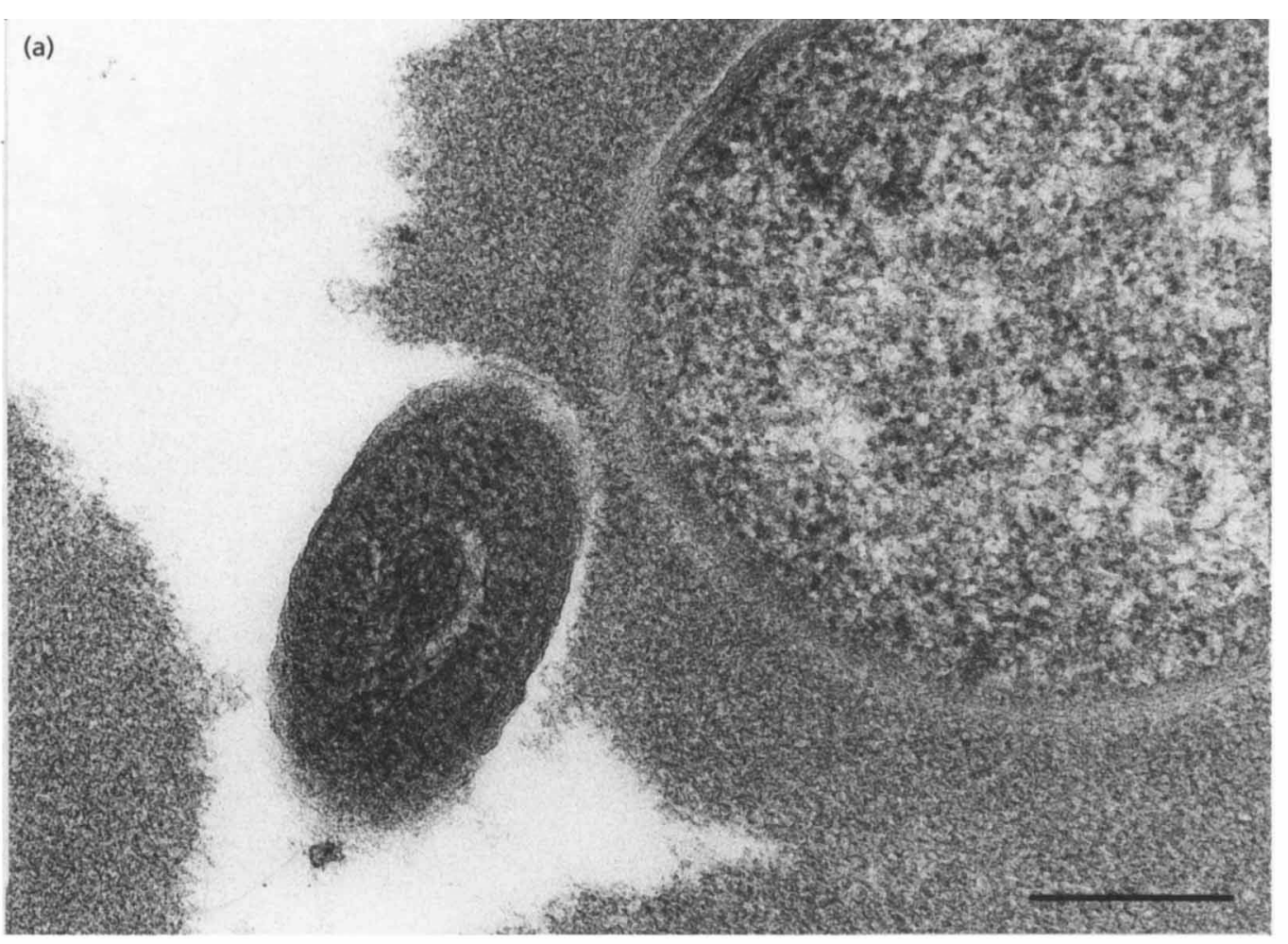

(b)

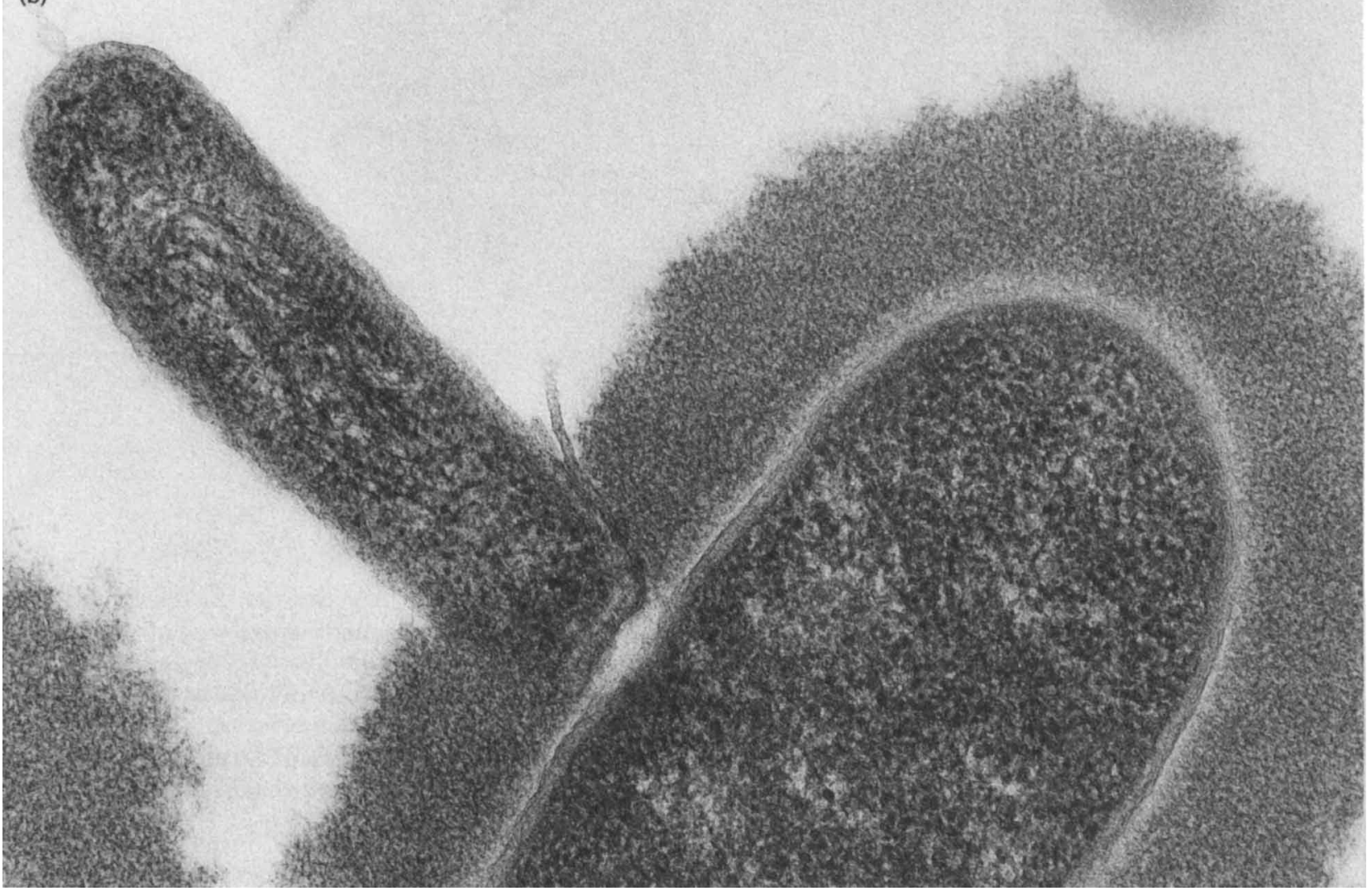

Fig. 3. Thin sections of capsulated $E$. coli $\mathrm{K} 29$ showing (a) partial penetration of the thick capsule by $B$. bacteriovorus and (b) attachment of B. bacteriovorus $109 \mathrm{~J}$ to the cell envelope. Bar, $200 \mathrm{~nm}$. 


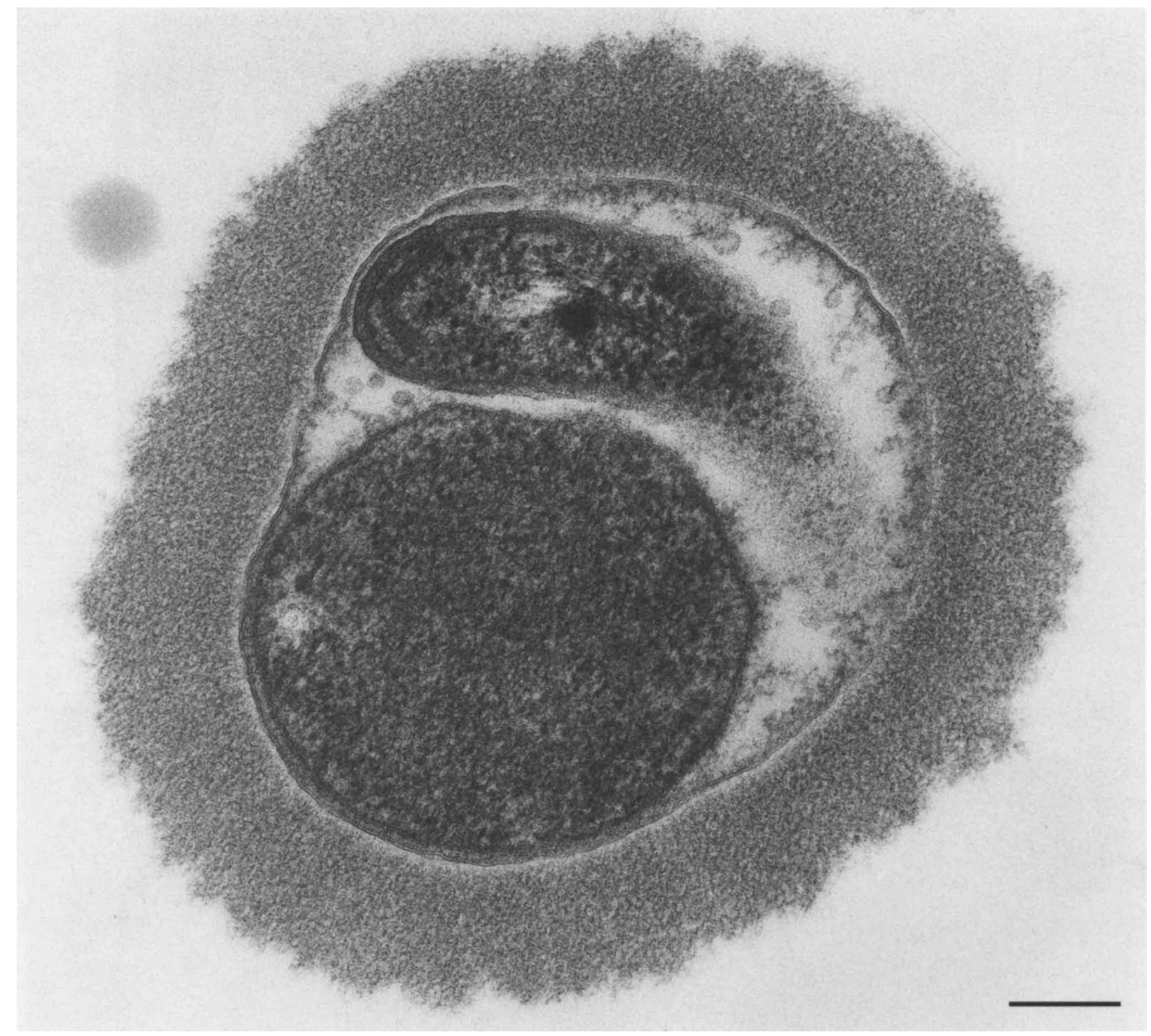

Fig. 4. Thin section of a capsulated bdelloplast of $E$. coli K29. Bar, $200 \mathrm{~nm}$.

capsule consists of more than $95 \%$ water (Sutherland, 1977), it provides a highly effective protection against macromolecular and viral attack. During collision with a capsulated cell, the bdellovibrio encounters the gel-like capsular matrix which is flexible and whose fibres are apparently not cross-linked. Bdellovibrios penetrated the thick capsule without disintegrating the neighbouring capsular matrix (Fig. 3). We did not attempt to determine the time required for penetration of the capsule. However, it cannot be very rapid, since many bdellovibrio cells were immobilized mid-way through the capsule (Fig. 3a).

In contrast to the diffusion-driven collision events between virus particles and host cell, B. bacteriovorus cells are actively propelled by flagellar activity and achieve surprisingly high speeds. The successful attachment of the bdellovibrio to capsulated prey cells most likely results from an increase in the area of contact during the deepening penetration, rather than from enzymic attack of the polysaccharide, as has been shown for capsule-specific bacteriophages (Fehmel et al., 1975; Bayer et al., 1979).

Another observation from our study was that more than one bdellovibrio could penetrate the capsule and that the resulting bdelloplast of E. coli K29 retained its capsule. Capsulated bdelloplasts could clearly be seen in India ink preparations for light microscopy (data not shown) and by electron microscopy (Fig. 4). This is the 
first report of a capsulated bdelloplast and demonstrates the stability of the anchoring of the capsular elements during bdelloplast formation.

Many freshwater and terrestrial Gram-positive bacteria possess capsules (e.g. Bacillus spp.) but are not suitable prey cells for $B$. bacteriovorus. The question of a protective anti-predation barrier for these organisms does not arise, whereas we demonstrate here that capsules of Gram-negative bacteria seem to fail as a protective barrier against predation by $B$. bacteriovorus.

\section{ACKNOWLEDGEMENTS}

We thank Dr Margret Bayer for the E. coli K29 cultures and K29 antisera, and Sean Waddick from Regina Mundi High School who assisted with the predation studies as part of a Cooperative Education Program in Science (London and Middlesex County Roman Catholic School Board). This work was supported in part by NSF grant DCB 8503684 (to M.B.) and NIH grant CA-06927 to the Fox Chase Cancer Center.

\section{REFERENCES}

Bayer, M. E. (1990). Visualization of the bacterial polysaccharide capsule. Curr Top Microbiol Immunol 150, 129-157.

Bayer, M. E. \& Sloyer, J. L., Jr (1990). The electrophoretic mobility of Gram-negative and Gram-positive bacteria: an electrokinetic analysis. J Gen Microbiol 136, 867-874.

Bayer, M. E., Thurow, H. \& Bayer, M. H. (1979). Penetration of the polysaccharide capsule of Escherichia coli (Bil 62/42) by bacteriophage K29. Virology 94, 95-118.

Bayer, M. E., Carlemalm, E. \& Kellenberger, E. (1985). Capsule of Escherichia coli K29: ultrastructural preservation and immunoelectron microscopy. J Bacteriol 162, 985-991.
Burnham, J. C. \& Conti, S. F. (1984). Genus Bdellovibrio Stolp and Starr 1963, 243 AL . In Bergey's Manual of Systematic Bacteriology, vol. 1, pp. 118-124. Edited by N. R. Krieg \& J. G. Holt. Baltimore: Williams \& Wilkins.

Dunn, J. E., Windom, G. E., Hansen, K. L. \& Seidler, R. J. (1974). Isolation and characterization of temperature-sensitive mutants of host-dependent Bdellovibrio bacteriovorus 109D. J Bacteriol 117, 1341-1349.

Fehmel, F., Feige, U., Niemann, H. \& Stirm, S. (1975). Escherichia coli capsule bacteriophages. VII. Bacteriophage 29-host capsular polysaccharide interactions. J Virol 16, 591-601.

Gray, K. M. \& Ruby, E. G. (1991). Intercellular signalling in the Bdellovibrio developmental cycle. In Microbial Cell-Cell Interactions, pp. 333-366. Edited by M. Dworkin. Washington, DC: American Society for Microbiology.

Koval, S. F. \& Hynes, S. H. (1991). Effect of paracrystalline protein surface layers on predation by Bdellovibrio bacteriovorus. $J$ Bacteriol 173, 2244-2249.

Moorhouse, R., Winter, W. T., Arnott, S. \& Bayer, M. E. (1977). Conformation and molecular organization in fibers of the capsular polysaccharide from Escherichia coli M41 mutant. J Mol Biol 109, 373-391.

Ruby, E. G. (1992). The genus Bdellovibrio. In The Prokaryotes, pp. 3400-3415. Edited by A. Balows, H. G. Trüper, M. Dworkin, W. Harder \& K.-H. Schleifer. New York: Springer.

Sutherland, I. W. (1977). Bacterial exopolysaccharides, their nature and production. In Surface Carbohydrates of the Procaryotic Cell, pp. 27-96. Edited by I. W. Sutherland. London: Academic Press.

Received 26 June 1996; revised 14 October 1996; accepted 1 November 1996. 